\title{
Morele Herbewapening
}

Die beweging bekend onder hierdie naam is 'n ou bekende wat nou onder 'n ander naam presies dieselfde leer verkondig as wat in Suid-Afrika reeds in die twintiger jare baie goed bekend was. Destyds was dit alombekend as die OXFORD-GROEP, en wel vanweë die rol wat sekere studente uit die Universiteit van Oxford daarin gespeel het. Inderdaad is op 'n huissamekoms in Oxford 'n sekere Hamilton vir Christus gewin, en hy het op sy beurt weer ' $n$ Rhodes-student uit Rhodesië met die naam van Richardson sogenaamd bekeer. Die heer Richardson het met ses ander Oxford-studente die beweging in Suid-Afrika geloods in 1927 en die eerste samekoms in ons land was te Schoenmakerskop, Port Elizabeth, in 1928. Baie ander Groepe is toe oral in ons land gestig. 'n Hele span entoesiaste uit Amerika. Engeland en Holland onder die persoonlike leiding van die stigter van hierdie Beweging, dr. Frank N. D. Buchman, het in 1929 ons land besoek.

Met entoesiasme is die Oxfordgroep hier deur Engelse kerke en ook een van ons Afrikaanse kerke begroet en is daar gebid om seën op die werk om ontroue kerkgangers na die kerk terug te bring en troue kerkgangers verder te begeester. In De Kerkbode (24 Sept. 1930) lees ons: ,dat Gods Gees die Beweging gebruik het tot vernuwing van lewens, kan nie ontken word nie, sodat wie hom daarteen stel, gevonde kan word as strydende teen die Gees van die Heer".

Sinds 1938, toe die Oxfordgroep duidelik gefaal het in sy vooropgestelde roeping, uitgedien geraak het omdat hy niks nuuts kon bring nie, veroordeeld gestaan het in sy beginselgrondslag, die kerke hulle van hierdie Beweging gedistansieer het omdat hy die geestelike lewe veroppervlakkig het, is deur dieselfde dr. Buchman weer 'n stoot aan dieselfde Beweging gegee en nou onder 'n nuwe naam: MORAL REARMAMENT-Morele Herbewapening.

In 1931 skryf wyle ds. P. G. W. Snyman al dat besware opgesom kan word in die volgende: 'n valse mistisisme, valse optimisme en valse idealisme. Hy beskou sy beginsels as valse en ketterse grondslae, veroordeel hul metode as rewolusie teen die kerk en as vroom bedrog. Die Oxfordgroep, so skryf hy, is 'n klap in die gesig van die kerk. Geen wonder dat die vroeëre entoesiasme volkome bedaar het en dat die Oxfordgroep se aktiwiteite hier versterf het nie.

Niemand het dit ook betreur nie. Inderdaad is dit nie te veel gesê nie, want die Oxfordgroep het nie 'n leemte wat bestaan het opgevul nie, maar het eintlik verwarring kom stig. Met sy verdwyning het hierdie ver- 
warring in die geestelike lewe opgehou en het die kerke doodgewoon met hierdie geestelike werk voortgegaan. Met hul goed georganiseerde kerke en met die hoë waardering wat die Afrikaanse volk vir die kerklike werk het en vir diegene wat daarin werksaam is, het die regte orgaan hierdie verbondswerk voortgesit en was daar in die geestelike huishouding van die volk geen hongersnood nie.

En nou in 1938 herleef die Oxfordgroep weer, nie in 'n nuwe gedaante nie, maar net met 'n nuwe naam. Hy lyk op 'n identiese tweeling met sy vroeggestorwe broertjie, met uitgangspunt, metode en mikpunt. Hy vermy 'n eerlike ontleding van sy beginselgrondslag, maar wil veral die nadruk lê op die praktyk.

Dit klink al wonderlik: praktyk sonder teorie, lewe sonder beginsel,dit is seker net godsdiens wat sulke mense graag in so 'n verwarde toestand wil hou. Elke wetenskap het tog 'n grondslag, het tog sy beginsels. Dit is tog verantwoordelik om jouself vir alle vorme van kritiek te vrywaar. Het u al van 'n etiek sonder norm gehoor? Is daar dan 'n huis sonder fondament? Maar dikwels is dit die geval dat strominge in die godsdienstige lewe inkom wat werklik beginsels het, maar hulle wil die klem laat val op die praktyk, omdat die beginsels duidelik vals is. Dit kan 'n billike ondersoek uit die Bybel nie verdra nie. Maar dan moet ons ook weet dat die praktyk net so vals as die beginsels sal wees.

Morele Herbewapening is maar net 'n moderne naam wat moet pas by die wedloop om wapenrusting by die groot volkere. Geeneen van die skrywers probeer verberg dat dit maar net dieselfde Oxfordgroep van die verlede is nie. Die naam Oxf. Groep is net te niks-seggend. Buchman het gesê ,If you do not listen to guidance, you will listen to guns". Uit die ruine van die afgelope wêreldoorlog en tydens die verloop daarvan, het die gryse dr. F. N. D. Buchman weer opnuut 'n oproep gedoen tot geestelike herbewapening.

Niemand het hierteen beswaar nic-inteendeel. Indien volksleiers en kerkleiers dieselfde oproep laat hoor, verwelkom die kerke dit telkens. Dr. Buchman se tydige woord kan in elke jaar weer met klem herhaal word. Die saak is alleen of die Morele Herbewapening as Beweging hierin die leiding moet neem, soos wat hy wens te doen. Die vraag is: het ons hier te doen met 'n gesonde geestelike Beweging, en moet ons hier ons rigting vind?

Dan moet ons hierdie Beweging eers in sy prinsipe beoordeel. Ons moet cns ook nie laat af bring van 'n prinsipiële waardering nie. met die be- 
roep dat ons juis die praktyk moet beoordeel nie. Dit wil ons in hierdie stuk graag doen. En omdat die praktyk dan die vernaamste skyn te wees, sal ons veral daar 'n oomblik by stilstaan.

Eers 'n woord oor die stigter, dr. Buchman. Hy is in Pennsylvania, V.S.A. gebore in 'n godsdienstige en gasvrye, maar eenvoudige huis. Sy onderwys het hy hoofsaaklik aan Muhlenbergkollege geniet waar hy ook 'n eredoktorsgraad verwerf het.

Buchman se hart het uitgegaan tot die arme en misdeelde, en hy het 'n betrekking aanvaar as hoof van 'n groot kinderhuis. Toe die direkteure van hierdie inrigting aan hom opgedra het om drasties te bespaar vanweë 'n finansiële tekort, is hy met wrok teen hulle daar weg.

Later was hierdie optrede van hom juis die keerpunt in sy lewe. Toe daar ' $n$ verandering in sy lewe gekom het, het hy aan elke direkteur ' $n$ hartelike brief van verskoning geskryf. Na hierdie daad wat hy as die belangrikste daad van sy lewe beskou omdat hy bereid was om nie net self te verander in sy houding teenoor die met wie hy in onmin leef nie, maar ook vir ander 'n spoorslag tot sodanige verandering te wees, het hy dit as die geestelike metode tot sedelike herbewapening aanbeveel. Dit is eintlik die kern van sy beweging: ons moet aan mekaar ons sonde bely en nadat ons sover gekom het om dit te doen, moet ons ambassadeurs wees om ook ander tot so'n insig te bring.

Hierdie hele geestelike houding is eintlik te naïef om daaroor te skryf. Sodra 'n mens die hele geestesinhoud van die Beweging van Buchman deurgesien het, voel jy ook om te sê dat die godsdienstige waarde-inhoud daarvan soveel is as wat 'n mens op 'n trippens kan skryf. 'n Mens sou sê dat dit eintlik werklik die minimum is wat 'n mens van enige Christen kan verwag. En as dit die ganse geestelike inhoud is, as dit die maksimum van ons godsdiens moet wees--wel, dan is dit maar' $n$ armoedige Christendom, Werklik, dan is die voedsame kos uit die kinderinrigting almal weggeneem en net die floutste soppies het oorgebly as teerkos vir die volgelinge van Sedelike Herbewapening.

'n Mens vra jou af of dit nou werklik die nuwe is waarmee die wêreld moet kennis maak. Dit is tog werklik die minste wat die Christendom eis. Dit is waarlik nie eers 'n tipies Christelike eis nie, want dit is die weg van gewone ordentlikheid. 'n Mens sou kan sê dat dit die doodgewone kultuureis. die gewone beskawing se elementêrste begin is. Dit sal seker ook nog wel duideliker word as ons verder gaan. 


\section{WAT IS MORELE HERBEWAPENING?}

Om hierdie vraag te beantwoord moet ons die angste van die wêreld deurleef. Dr. Buchman het duidelik besef dat daar 'n sentrale kwaal is wat gemeenskaplik is aan al die volke. Dit skyn asof sy vinger duidelik wys na die feit dat die mensheid van die twintigste eeu godloos geword het. Godloos grens aan goddeloos en is die begin daarvan. Die smarte van huidige gebeurtenisse in oorloë en die naweë telkens daarvan, is niks anders as geweldige oordele van God oor volkere en nasies wat God-loos geword net nie en daaraan sal die nasies ondergaan.

God-loos, want hulle dryf op eie wieke. Vandaar dat hulle hul selfstandigheid soek by die materialisme en hul veiligheid in besit, in opgegaarde besit (Kapitalisme), in werk en loon.

God-loos, omdat nie gevra word na Gods voorsienigheid en leiding nie.

God-loos, omdat die mensheid buite verband met God geraak het.

God-loos, omdat die nasies nie meer Gods stem uit Gods Woord beluister nie.

God-loos, omdat die nasies nie meer oorgiet word deur die heldere strale van Goddelike lig nie en almal buite die aanraking met die goddelike kragstasie te staan gekom het (Vgl. The Message of Frank Buchman p. 33).

God-loos, omdat God nie meer die daelikse ervaring in baie se lewens is nie.

Daarom het die Morele Herbewapening gekom om benewens die werk van die kerk te laat hoor: terug na God toe. Die mens van die twintigste eeu het verleer om God te sê. Hy moet God weer leer ken. Hy moet God aan die stuur plaas en God moet die ,directing force" (stuurkrag) word in sy lewe.

Hoe moet hierdie mooi taak verrig word? Is daar persone, liggame, verenigings, kerke met hierdie taak besig? Het ander ook al dieselfde diagnose van die kwaal van die nasies gemaak? Indien hierdie werk al deeglik gedoen word, waarom dan nog 'n ander beweging?

Laat ons hoor wat Morele Herbewapening van homself sê. P. Howard sê in sy boekie „,A Renaissance that unites East and West”, p. 9 vv.: ,,Moral Rearmament is not just a personal matter ..... it is not a moral movement ..... it is not goodwill. It is a revolution, to bring social, political, economic, national and supra-national change, a whole new range of motives to the whole world ..... It is the ideology of freedom, the ideology of renaissance". Vertaling: Morele Herbewapening is nie net 'n persoonlike saak nie .... dit is nie 'n sedelike beweging nie ..... dit is nie toegeneent- 
heid nie..... Dit is 'n rewolusie en wil sosiale, politieke, ekonomiese, nasionale en supranasionale veranderinge teweegbring. Dit is ' $n$ ideologie van vryheid en van renaissance.

Die antwoord op die vraag wat Morele Herbewapening is, is dus: dit is ' $n$ rewolusie. Hierdie rewolusie wil drie dinge teweegbring:
I. God-control
- Godsbestuur.
II. Change
- Verandering.
III. Guidance
- Leiding.

Hierdie drie sake is eintlik die antwoord op drie sentrale vrae wat elke mens hom moet afvra:

1. Welke plek neem God in my lewe in?.... Godsbestuur.

II. Hoe word die verhouding tot God bewerkstellig?..... deur verandering in my lewe.

III. Hoe geskied die verandering? ..... deur leiding.

Rondom hierdie drie kern-sake word 'n mens se hele lewe gegroepeer. Die mens se hele lewe moet hierdie drie sentrale eise vertoon.

I. Godsbestuur:

Morele Herbewapening stel hom hoofsaaklik teen die verafgodiserende materialisme wat soos 'n groot Molog sy duisende verslind. Geestelike waardes het in onguns geraak. Kwaliteit kan die wedloop teen kwantiteit nie wen nie. Vandaar dat daar 'n verandering moet kom. Getuie hiervan is die opkoms van sekere ideologieë: Kommunisme, Fascisme, Sosialisme.

Nou kan teen hierdie ideologieë oorlog verklaar word en hulle kan oorwin word. Daarmee het ' $n$ mens hulle werklik nog nie oorwin en uitgeroei nie. Daar moet in die hart van die mens, van die persoon, 'n verandering kom en hierdie verandering kan geen mens bewerkstellig nie. Dit moet deur God bewerk word (Remaking the World, p. 86). Ons moet gehoorsaam met God saamwerk.

Omrede die insig dat alle ideologieë rewolusies is, word ook hierdie beweging 'n rewolusie genoem. Hier moet egter duidelik gestel word dat hierdie Bewegting hom nie op Gods Woord beroep om sy uitgangspunt of doelstelling te verklaar nie. 'n Mens sou verwag dat 'n diepere grondslag as 'n reeks pikante gesegdes gesoek sal word om te verklaar waarom die Herbewapeningsbeweging juis ' $n$ rewolusionêre moet wees en waarom elke lid juis 'n rewolusionêr moet wees. Hierdie slagwoorde maak op 'n mens nie juis 'n magtige indruk nie, en tog word hierdie slagspreuke as lyfspreuke van dr. Buchman wat hy bykans in al sy toesprake gebruik ten oorvloede toe aangehaal. Ek noem hulle. ,.The Oxford Group's answer to revolution 
is more revolution". (Remaking the World, p. 37). "God-controlled individuals, God-controlled homes, God-controlled schools, God-controlled industry, God-controlled politics, God-controlled nations. This means that everybody takes his orders from God”. (a.w. p. 31). Voorts: „Godcontrolled personalities make God-controlled nationalities (a.w. 26). „Only a passion can cure a passion". (a.w. 163).

'n Mens kry die indruk dat die hele Beweging gegrond is op hierdie slagspreuke van dr. Buchman, juis omdat die Bybel totaal ontbreek, selfs verklarings in Bybelse trant. Hierdie gesegdes is meesal volkome onjuis, soos die laaste wel getuig. Die Skrif sê daar: ,'n sagte antwoord keer die grimmigheid af".

Rewolusie is ' $n$ verkeerde woord en ' $n$ totaal verkeerde begrip. Iemand wat die Bybel ter hand neem, is 'n anti-rewolusionêr. As hier liewer gestaan het dat die antwoord van die Morele Herbewapenings-beweging op rewolusie is Jesus Christus, sou dit positief 'n geweldige inslag gehad het en suiwer gewees het. 'n Mens vind hier 'n geheul met wêreldse begrippe wat vreemd is aan die geestelike (en veral die Skriftuurlike) literatuur. Ek vind dit 'n geweldige gemis dat die Bybel nie spreek nie, maar Buchman, hoe 'n deeglike mens hy ook al mag wees. Ek vind dit 'n geweldige tekort wat nooit weer aangevul kan word nie, dat 'n mens met die taal en die daad van die wêreld moet antwoord: „revolution..... passion”. Hoe kan God die bestuur van alles hê, as sy Woord sodanig misken word?

Op welke wyse moet daar nou meer Godsbestuur (God-control) in die wêreld kom?

Die leiers van die Morele Herbewapening sê: deur middel van hierdie organisasie.

Hiermee word natuurlik by implikasie beweer dat die bestaande organisasies en bewegings wat op hierdie terrein beweeg, daartoe nie in staat is nie, getoets is en te lig bevind is, onmagtig geblyk het. Die kerke moet natuurlik ook dit hoor, hoewel die edele doel van hierdie Beweging is om die kerke weer vol te kry. Aan die kerke word dit verwyt dat hulle leeg loop, dat daar geen belangstelling is vir die verkondiging van die Woord soos dit daar geskied nie.

As dit gaan oor hierdie gewaardeerde terugkeer en mooi roeping, sou 'n mens verwag dat aan ons gesê word wat die beswaar is teen die bestaande organisasies bv. kerke en Christelike verenigings. 'n Mens verkeer hier waarlik nie op 'n braakland, op 'n verlate pad nie. As daar ooit iewers 'n druk verkeer is, is dit juis op hierdie gebied van die geestelike lewe. Volk en maatskappy is werklik hier nie swak bedeeld nie. 
Teen die doelstelling, nl. God-control, sal nergens beswaar gevind word nie. Dit is immers 'n kardinale stuk van die belydenis van al ons kerke. Sal ek aanhaal uit die verklaring van die Heidelbergse Kategismus wat ons bely aangaande Godsbestuur?

Ek doen dit uit Sondag IX en X. Daar word aan ons gevra wat ons glo met die woorde uit die Twaalf Artikels: Ek glo in God, die Vader, die Almagtige, die Skepper van hemel en aarde.

„Dat die ewige Vader van onse Here Jesus Christus wat hemel en aarde, met alles wat daarin is, uit niks geskape het, wat ook deur sy ewige Raad en voorsienigheid dit nog onderhou en regeer, ter wille van sy Seun Christus my God en my Vader is....."

Die antwoord op die vraag wat ons onder die voorsienigheid van God verstaan is: „Die almagtige en alomteenwoordige krag van God, waardeur Hy hemel en aarde en al die skepsele as met sy hand nog onderhou en so regeer dat lower en gras, reën en droogte, gesondheid en krankheid, rykdom en armoede en alle dinge nie by toeval nie, maar uit sy vaderlike hand ons toekom".

God-control-ja, want God is alomteenwoordig en almagtig, altyd by ons en geen enkele sekonde is ons sonder God nie.

Godsbestuur-die nasies staan daaronder en die persone, selfs die goddelose staan daaronder tesame met Satan self, wat ook magteloos is, as God nie wil nie.

Hier lê die kardinale fout van die Beweging: hy wil God aan die stuur plaas. En al die tyd is God daar en niemand kan God daar ooit wegneem nie. En omdat God nog altyd die Allerhoogste Koning is oor hemel en aarde, kan geen Beweging hom aangord om God terug te bring waar Hy nog altyd is nie. Die kerke kan dit ook nie doen nie-en doen dit ook nie. Die kerke verkondig dit alleen dat God daar is, en dat dit die mooiste en troosrykste is van ons belydenis. Die kerke gaan uit van die heerlike geloofswetenskap: God Regeer. Daarom juis kan niks en niemand ons uit Gods hand ruk nie-daarom juis kan die poorte van die doderyk die kerk nie oorweldig nie.

Ons vind dus hier dat daar God-control is en nie dat dit daar moet wees nie. Hier het ons daardie mooi vroom gedagtes, maar as ons dit begin ontleed, is dit 'n stukkie sonde. Hier word God in sy hoogheid aangetas, gedink dat God nie Koning is en Regeerder oor al wat daar leef nie. Ons moet God Koning maak. God het ons dus nodig. Sy Koningskap is van ons afhanklik. Morele Herbewapening sal God kom kroon. 
En intussen het Morele Herbewapening eintlik die kroon van God af kom wegneem. As God van ons afhanklik moet wees dat ons Hom moet kroon-ag, dan is ons meer as God. En dit is goddeloos.

\section{Change-Verandering.}

Die taak en roeping om Godsbestuur in die wêreld in te bring kan alleen vervul word as daar' $n$ persoonlike verandering plaasvind. Hierdie persoonlike verandering word aangedui met die enkele woordjie ,change”. Tog verkry hierdie woordjie geleidelik 'n teologiese en ook 'n konfessionele karakter. As ons begin navraag doen, hoe geskied die verandering? en deur wie? dan gaan die deure oop.

Ons begin hier om weer te sê dat 'n mens tevergeefs soek na skriftuurlike woorde in die geskrifte of selfs gedagtes wat verwys na iets wat in die Bybel aangetref word. Ons vind hier weer die gewone slagspreuke wat in toesprake en geskrifte van dr. Buchman voorkom: ,as die mens luister, spreek God; as die mens gehoorsaam, handel God; as mense verander, verander nasies".

Dit ontgaan 'n mens natuurlik nie dat die mens elke keer eerste genoem word en in 'n nogal leidende posisie geplaas word. 'n Mens kan natuurlik ook bogenoemde sinsnedes negatief plaas en dan kom die betekenis daarvan miskien duideliker aan die lig. Kan ons dit maar doen? „As die mens nie luister nie, spreek God nie; as die mens nie gehoorsaam nie, handel God nie...." Kan ons nog saamstem? Is God al weer afhanklik van die mens? Die mens kan God eintlik tot magteloosheid bring. Dit hang net van hom af of God kan spreek en kan handel.

Laat ons egter voortgaan. Vanweë die bogenoemde uitgangspunt gaan die voorstanders van die Morele Herbewapening nou voort en sê: daarom moet daar 'n verandering plaasvind. Hierdie Beweging sal nou die program aandui wat uitgevoer moet word, sodat die nasies veiligheid, vastigheid en sekerheid kan verkry. Elke man, vrou en kind word opgekommandeer en elke huis moet 'n vesting word. Buchman sê: ek wil die millioene bereik. Hy skrywe: .,Net Morele Herbewapening kan die nasies aan mekaar bind". (Remaking the World, p. 65).

Die rol van hierdie Beweging word dus hoog aangeslaan. Die grotes van die wêreld en die leiers van die nasies word gesoek. President Truman en pres. Roosevelt se boodskappe van steun word besonderlik genoem. 240 lede van die Britse Laerhuis sowel as 'n uitgesoekte groep van die lede van die Hoërhuis. het steun beloof. Gedurende die oorlog het die Morele 
Herbewapening, so word gesê, wonders gedoen deur die regte gees en gesindheid te bewerkstellig tussen werkgewer en werknemer. Daar word aangehaal uit die offisiële Roomse en pouslike blad Osservatore Romano dat die Pous die Morele Herbewapening ,'n kragtige hulp in die Pous se daelikse poging om die siele en die wêreld na die deugde van die Evangelies te roep", beskou. (a.w. 123).

Nog net één aanhaling om te bewys dat die Morele Herbewapening sy taak hoog aanslaan: „The man who opened the eyes of the whole civilised world to the fact that purely political and economic means were inadequate to meet the situation was the founder of Moral Re-armament, Dr. Frank Buchman" (a.w. 244).

Hoe geskied die verandering?

Hierdie begrip behou nie deurgaans dieselfde betekenis nie. Soms word nogal suiwer gestel ,wanneer die H. Gees van God die harte en lewens van mense regeer, dan sal ons die nuwe wêreld van môre wat ons almal begeer om te sien, begin bou" (a.w. 146). Hiermee in verband hoor ons ook van ' $n$ verandering in die menslike natuur wat God alleen kan bewerkstellig (The message of Frank Buchman, p. 15). En dan weer „MRA stands for the dictatorship of the Holy Spirit, (a.w. 15 en Remaking the World, pp. 4 en 41).

Die menslike natuur wat verander moet word is inherent goed en is tog nie goed genoeg nie en daarom moet dit verander word (Remaking the World, p. 152). Hierdie verandering begin plaasvind van die tyd af dat God deurgang verleen word (a.w. 39). Daar is slegs twee soorte mense in die wêreld: die wat verander is en die wat nie verander is nie (a.w. 237).

Daar is vier stappe in die verandering: (Remaking the World, $68 \mathrm{v}$. en The Message of Fr. Buchman, p. 34 v.)

Die eerste is dat elke mens die absolute norme nl. eerlikheid, reinheid, onselfsugtigheid en liefde, moet toepas in sy lewe. Die mees praktiese wyse om dit te doen is om die vier norme op te skryf en dit as 'n maatstaf te gebruik deur jou lewe daaraan elke dag te meet. Met volle eerlikheid moet jy elke dag jou lewe opteken en dan sal dit duidelik word waar jy moet verander.

Die tweede is dat jy openhartig met 'n vriend van jou moet gesels oor dit wat jy in jou eie lewe gevind het. Onmiddellik kom die skaamte op, maar eerlikheid moet 'n mens verplig om alles te vertel wat in eie lewe skeef en krom gegaan het ten opsigte van die vier bogenoemde norme. 
Die derde stap is om vas te stel teenoor wie jy verskonings moet aanbied vir jou verkeerde optrede. As ons berouvol is, sal ons vergewing vra aan God en ons naaste. Vergiffenis vra is nie vernederend nie, maar verheffend. Dit is die veredelende ervaring dat jy reg maak wat verkeerd was en wat altyd verkeerd sou bly as jy nie uit eie beweging dit weer reg gemaak het nie.

Die vierde stap is om te erken dat daar ' $\mathrm{n}$ Hoër Wil is en dat $\mathrm{Hy}$ juis die rigtinggewende krag in jou lewe is. Aan hierdie Hoër Wil moet ons onderhorig wees. Dit moet ons 'n vreugde wees om die koers te volg wat Hy aangee. Oorgegewenheid aan hierdie Hoër Wil is om jouself volkome prys te gee. Dit is soos Paulus dit uitgeroep het: Ek sterf elke dag, broeders.

Ons moet hier wys op die belangrike plek wat verandering inneem in die hele inrigting van die Morele Herbewapeningsbeweging. Ons moet onthou dat hulle nie teorie nie, maar praktyk wil wees, en hier het ons nou die eerste deel van die praktyk: VERANDERING.

'n Mens kan nie beweer dat die Bybel darem heeltemal vergeet word in die uitgawes van hierdie Beweging nie. Dit word nu en dan selfs beklemtoon dat ons moet luister na Gods Woord.

Wat egter baie duidelik is, is dat die Bybel onder andere 'n plek verkry, en ons wil dit só verduidelik.

In verandering is tog nodig 'n reël, 'n maatstaf. Hoe sal dit dan geskied? Ons sou sê dat die Bybel so 'n reël of maatstaf is. Buchman skryf „One test is the Bible". Daar moet dus ook ander reèls wees. 'n Mens word ook volkome in die duister gelaat insake die verband tussen hierdie gedagte van verandering en die Bybelse woord bekering. Sou daar verband wees, veral as die $\mathbf{H}$. Gees ook in hierdie werking betrokke is?

Ons wil hier weer sê dat dit darem jammer is dat ook hier weer blyk dat die Bybel verbygegaan word. In 'n boekie getitel ,A Renaissance that unites East and West" kom sterk en ingrypende woorde voor oor wat Morele Herbewapening wil doen. Dit wil die Ooste en Weste tot 'n eenheid saamvoeg. Dit wil 'n ganse ommekeer, 'n renaissance bewerkstellig, 'n nuwe tipe wêreld bou met 'n nuwe tipe mens wat daarin woon, wil hoop gee aan 'n moedelose wêreld. „It is a world-wide transformation of human society that has already begun .....". En nie 'n enkele beroep op Gods Woord nie. Geen enkele aanhaling om aan te toon dat die Bybel 'n enige plek inneem nie. Hier word inderdaad niks van God-control gehoor nie. God spreek tog tot ons uit sy Woord, maar as hierdie Woord onbekend is en nie eers gebruik word nie, dan skyn dit my asof ons hier met 'n vreemde verskynsel te doen het. Hoe moet 'n mens hierdie swygsaamheid oor Gods Woord 
verklaar? Ook hier word dit weer alles Buchman. Buchman het SuidAfrika besoek en die kleurskeidslyn het gebreek. Hy los volksprobleme op.

Maar voorts: verandering veronderstel ten minste 'n slegte toestand wat jou verplig om 'n verandering te maak. Wat is dan so sleg of verkeerd? Is dit die natuur van die mens? Nee, Buchman sê dat die natuur van die mens inherent goed is. Is dit die sonde wat hy gedoen het of nog doen? Vanwaar die behoefte aan verandering?

Dit is ' $n$ baie noodsaaklike en wesenlike vraag.

Buchman sê-en hy gaan maklik daaroor heen, wat 'n bewys is dat hy die saak van sonde ook nie baie ernstig neem nie-, I said ,sorry'-first to God, then to those I had wronged ("Remaking the World, 168). As ons dit in Afrikaans vertaal, sien ons dadelik waar dit omgaan. „Verskoon my, het ek aan God gesê, en aan persone wat ek gegrief het". Met ander woorde: ons het hier nie die Bybelse leer van vergiffenis nie, maar die onskriftuurlike leer van verskoning. Hier is daar sommer 'n groot skroef los.

Die leerstuk van vergiffenis eis dat iemand vir die sonde en oortredinge moet betaal, moet boet, moet genoegdoening verskaf. As ek egter net maar ekskuus kan vra, verskoning aan God kan aanbied, dan weeg sonde by Buchman bepaald nie swaar nie. Sonde is ook glad nie iets verskrikliks nie, nie vir God nie en ook nie vir die mens nie. 'n Mens sou die hele Bybel nie kan verstaan as hierdie onbybelse leer van verskoning sou aanvaar word nie.

Kan u my sê: kan by so 'n ligvaardige gedagte oor sonde nog sprake wees van ' $n$ oordeel van God, van 'n ewige oordeel? Kan daar sprake wees van ewige verdoemenis omdat die mens die ewige God se majesteit geskend het? En is daar plek vir die kruis en vir die Gekruisigde? As 'n mens kan verskoning vra en so verlos word van jou sondes, wat moes Christus dan nog vir ons doen? Moes Christus dan maar gekruisig word vir'n simboolof is die kruis werklik waardeloos? My slotvraag is: het die mense van Morele Herbewapening die Bybel gelees-gelees en verstaan?

Luister na hierdie stukkie onskriftuurlike woorde: „The four stages to get rid of sin are to hate it, to forsake it, get honest about it and restore for it by putting things right" (Remaking men, 94). Waar staan dit in Gods Woord? Is dit moontlik dat dit in Gods Woord kan staan? En wat dan van Jesus Christus? Is Hy dan nog Middelaar en Borg?

Buchman antwoord: „There, culminating in the life of Jesus Christ, we find the highest moral and spiritual challenge-complete honesty, purity, unselfishness and love" (Remaking the World, p. 36). 
Dit is nie woorde tot eer van Jesus Christus nie. Inteendeel, dit is juis Godslastering. Christus is ons Borg en Saligmaker, die Enigste Naam in hemel en op aarde deur wie daar redding is. Hy is nie maar die uitnemende voorbeeld van Buchman se vier norme nie. En waar staan dit in die Bybel dat Christus die hoogste sedelike uitdaging is?

Nee, die Skrif loënstraf elke woord aangaande sonde.

Dikwels tref ons die woord ,cure”, gesondmaking, aan. Sonde is dan siekte en genesing daarvan is ons taak en roeping. Daar het ons die tipiese remonstrantse dwaling. Buchman se eie verandering, nadat hy briewe van verskoning gerig het aan elkeen van die ses direkteure van die kinderinrigting, is hiervan 'n duidelike bewys. Christus het aan hom niks gedoen nie. Die H. Gees het ook weinig gedoen. Hyself het alles gedoen: hy het geskryf, verskoning aangebied-en van daardie dag af was hy'n nuwe mens.

Hier het ons een van die geweldige mankplekke in hierdie beweging: sy flou sondebegrip. Dit is die sankdol waarop 'n huis gebou word wat nie anders kan as om in te stort nie. Hier is nie diep gegrawe nie. En die gevolg?

Sonde is net maar 'n misdaad.

Sonde is maar net 'n oortreding teen jou medemens waarvoor jy kan verskoning vra.

Sonde bring nie skuld en smet nie.

Nee, dit is sonde juis nie. Daar is nie eers soiets soos sonde teen my naaste nie. Sonde is altyd teenoor God. Sonde teen my naaste is eintlik anders. Ek steel my naaste se goed en dit is ' $n$ oortreding. Dieselfde daad is 'n oortreding van Gods wet en dit maak my 'n sondaar voor God. Teenoor my naaste kan ek 'n wandaad pleeg, kan ek onvriendelik of buffelagtig wees, kan ek my vergryp. Maar teenoor God is ek dadelik 'n sondaar, 'n ongeregtige, 'n skuldige. Ek het Gods majesteit geskend. Hierdie sonde maak my doemwaardig. Ek word daardeur besoedel, besmet. Ek kan nie maar net sê ,sorry" nie.

Nee-wat word van 'n dief wat gesteel het, en aan die gereg, as die polisie hom arresteer, sê : ,sorry"? Is die saak daarmee afgehandel? Geen sprake daarvan nie. Hy moet nog gevonnis word en vergelding doen vir sy daad.

Ons moet hier dus diep grawe. As ons sondebegrip flou en oppervlakkig is, gaan Christus vir ons verlore in sy volle rykdom. Dan word Christus vir ons maar slegs ' $n$ voorbeeld. Dan word ons godsdiens nie meer 'n verlossingsgodsdiens nie maar 'n verbeteringsgodsdiens. In plaas daarvan dat Christus in my plek kom staan het, kom ly het, gesterf het, kom be- 
taal het, sodat ek nou niks meer skuld nie, skoongewas is in sy bloed, is Christus vir my eintlik niks nie.

As sonde nie opkom uit ons verdorwe natuur nie, as ons nie in sonde ontvang en gebore word nie, as ons nie totaal bedorwe is en tot niks goeds in staat nie, kan ons nie verstaan waarom word die Seun van God Jesus Christus genoem nie. Dan wil ek saam met die Heidelbergse Kategismus aan diesulkes vra: Glo hulle dan ook in die enigste Saligmaker Jesus, wat hulle saligheid en welsyn by die heiliges, by hulleself of êrens anders soek? En dan antwoord: Nee; maar hulle verloën met die daad die enigste Heiland Jesus, ofskoon hulle met die mond in Hom roem; want een van twee: óf Jesus is geen volkome Saligmaker nie, of die wat hierdie Saligmaker met 'n ware geloof aanneem. moet alles in Hom hê wat vir hulle saligheid nodig is.

Kan 'n mens nou verstaan waarom in plaas van die Bybelse woord „bekering" die veel swakkere woord ,verandering" gebruik word?

Omtrent bekering word gesê dat dit uit twee dele bestaan: die afsterwing van die ou mens en die opstanding van die nuwe mens. Daar het ons woorde wat getuig dat daar diep gegrawe word: niks minder as dood en opstanding is nodig nie. Hier is Christus die enigste naam. Hier is Hy alles en ek is niks nie.

Weet u wat ,.change" is? Dit is die toepassing van 'n paar norme in my lewe. Dit is openhartige geselskap met ' $n$ vriend om aan hom my binneste mee te deel. Dit is verskoning vra vir leed aangedoen. Dit is die erkenning van 'n Hoër wil in my lewe.

Voel $u$ ook hoe flou dit alles is?

Is daar ' $n$ keuse tussen die Skriftuurlike leer wat die kerk aan u bring en die vermenslikte Buchmanisme wat die Morele Herbewapening bring?

\section{Guidance-Leiding.}

Hier het ons die derde belangrike deel in praktiese lewe van God-control, Godsbestuur. Ons moet goed aandag hieraan gee, want in die praktyk van ons godsdienstige lewe het ons hier te doen met die persoonlike en gemoedelike omgang met God. Dit kan iets moois wees, maar vanweë die vaagheid, kan dit 'n onkontroleerbare iets wees.

Buchman het nog in sy Oxfordgroep-tydperk besondere klem gelê op 'n stille tyd, vroeg in die more as alles nog rustig om jou is. „When man listens, God speaks" (Remaking the World, 35). Daarom moet die mens geleer word om aandagtig te luister. Enigeen, so sê Buchman, kan die woorde van die Here hoor (a.w. 36). Ons moet net die reëls gehoorsaam, $\mathrm{nl}$. ons moet eerlik luister. Dit is wenslik dat ons alles neerskryf. Die volgende 
reel is dat ons die gedagtes wat in ons opkom moet toets om te sien welke van hulle van God af kom.

Dit klink baie eenvoudig.

Goddelike leiding moet die normale deel word, die alledaagse ervaring van elke mens. Buchman is hieroor entoesiasties en beweer dat alle mense goddelike boodskappe kan ontvang, as hulle opvangtoestel maar net reg ingestel is. Die H. Gees is die geestelike wonderkrag. „The Holy Spirit is the most intelligent source of information in the world today. He has the answer to every problem. Everywhere when men will let $\mathrm{Him}, \mathrm{He}$ is teaching them how to live". (a.w. 14).

Oor hierdie saak is daar veel geskryf deur voorstanders van hierdie Beweging. 'n Mens word soms verleẽ oor soveel naïwiteit. Afgesien van die radio-ontvangtoestel wat natuurlik 'n beeld is om die kontak en gemeenskap tussen ons en God te verklaar, word daar gespreek van die definitiewe, akkurate en adekwate informasie wat van die Gees van God na die gees van die mens kan kom en dit is moontlik vir elkeen wat sy bevele van God wil neem (a.w. 41).

Hoe en wanneer geskied die leiding?

Elke mens word deur iets gelei. Wat bepaal u koers? vra Buchman. Is dit $u$ begeertes? Is dit u sakboek? Is dit u vrees, $u$ vrou, $u$ man, of wat $u$ bure dink? Is dit ons eie selfsugtige voornemens, of ons nasie se belang-of ons vyande? (a.w. 39).

So mag dit nie wees nie, want leiding is wanneer God die stuur in hande het.

Buchman gee aan ons sy eie ervaring en dit is die moeite werd om daarna te luister.

"Shall I tell you what happens when I listen? I give my mind to disciplined direction. I find that God's thoughts can become my thoughts. Direct messages come from the mind of God to the mind of man-definite, direct, decisive. God speaks". (a.w. 40).

Wat moet ons doen?

Ons moet 'n stukkie papier neem en die gedagtes wat in ons opkom neerskryf, elke dag, elke more vroeg. Dit mag doodgewone dinge wees, maar wees net eerlik en skryf alles neer.

Dit wil nie sê dat God alles in ons bring nie. Ons moet dit wel toets. Die eerste toets is eerlikheid in die optekening. Die tweede toets is om te bepaal welke gedagtes kom van God af. Een middel om dit te toets is die Bybel.Van hierdie Bybel word nie gesê dat dit die Woord van God is nie. Daar word gesê ,It is steeped in the experience through the centuries 
of men who have dared, under divine revelation, to live experimentally with God" (a.w. 36). 'n Volgende toets is: wat sê ander mense wat ook na God luister. Dit is die ongeskrewe wet van gemeenskap. Geen mens kan op homself deur God gerig word nie. God spreek die duidelikste tot 'n groep gewillige manne en vroue, want deur God-gerigte persone moet God eendag die wêreld regeer (a.w. 36). Op hierdie wyse regeer die H. Gees eintlik die harte en lewens en word'n nuwe wêreld gebou. Buchman is oortuig dat die bedeling van Geestesleiding nou met die Morele Herbewapeningsbeweging aangebreek en ingetree het (a.w. p. 146).

Prof. H. Bavinck skryf dat as elke mens maar bokant die poort van sy wetenskap-en dit kan ook voor in sy boek-wil skryf wie sy God is en wat hy van God dink, sal dit 'n mens die moeite spaar om die boek te lees. Ek het ook al so gewens dat dr. Buchman dit wou doen.

Hier word telkens van God gespreek en dan dink 'n mens, omdat hier sprake is van Christus en die H. Gees, dat'n mens moet aanvaar dat die Drieenige God bedoel word, die God van die Bybel. Mag dit maar so wees. Dit is my nie altyd ewe duidelik nie. Ons moet onthou dat hierdie Beweging Oos en Wes wil omspan. Die omvattendheid van die ideale van die Morele Herbewapeningsbeweging blyk uit baie stukke.

Bremer Hofmeyr skrywe in 'n pamflet „Hoe om te luister" die volgende: „Party mense glo in God. Vir hulle sal dit werk. Ander mense glo nie in God nie. Vir hulle sal dit ook werk". U sien hoe geloof en ongeloof ook verenig word. Inderdaad word hierdie ,guidance" of leiding van die Morele Herbewapening aanbeveel vir alle volke, gelowe, rigtings, of hulle katoliek, protestant, jood of heiden is (a.w. 111). „The great religions of the East feel at home with his teaching. The Koran says 'lead us to the good road'." Van Buchman word gesê dat ,he almost becomes a man of the Orient himself" en verder „His message is global. It is for any man, anywhere". (The significance of the life of Frank Buchman-Alan Thornhill, pp. 8, 9).

I u nog so oortuig dat die God van die Skrifte hier bedoel word? Hoe sal die Ooste hierdie God kan aanvaar? Of sou hier 'n blote Godsbegrip maar gegee word? Ek is van hierdie laaste oortuig. Morele Herbewapening verkondig aan ons nie die God van die Bybel nie. Dink weer net daaraan dat toe ons die begrip „Verandering” behandel het, een van die vereistes daarvoor was dat jy 'n Hoër Wil moet erken. Is dit 'n begrip of is dit God? Selfs ' $n$ man wat goddeloos is, kan nog 'n Hoër Wil erken. 
Dit pas ook goed by die Oosterse Godsbegrip. Hoe vager hoe beter. Dit moet so misties moontlik wees.

Dit pas by baie dinge mooi in: so 'n menslike opvatting van God. Pure humanisme, vermenslikte godsdiens met 'n vermenslikte God tot 'n Hoër Wil. Wie van ons sal ooit van God durf spreek as 'n Hoër Wil? Vir die gelowige is God ' $n$ Persoon, die hoogste Goddelike Persoon. $\mathrm{Hy}$ is meer: Hy is onse Vader om Christus ontwil.

En nou kan 'n mens ook verstaan waarom Gods roepstem tot bekering nie gebring word nie, maar die vermenslikte woord, verandering' verkies word.

En 'n mens kan ook verstaan dat Buchman nie 'n kerk kom stig het nie. By hom is dit te doen om aan 'n persoon 'n nuwe geestelike ervaring en verdieping te gee. Daarom wil hy met alle godsdienste van die Ooste en Weste saamwerk. Hy wil die millioene bereik. Daarom stel hierdie Beweging hom ten doel om organisasies in die lewe te roep, kontakte, wat Buchman selle noem. Huisgesinne, fabrieke, myne en orals waar 'n groep mense byeenkom, kan sulke selle wees. Een van die skrywers wat die Morele Herbewapening steun sê in sy boekie „A story of effective Statemanship” waarin die verhaal van Paulus se bekering gegee word, dat ook kerke selle is. Moet 'n mens hieruit aflei det kerke ook in diens van Morele Herbewapening staan? Ons het dan gedink dat die posisie omgekeerd is en dat Morele Herbewapening hom in diens van die kerke stel.

Vanweë hierdie belangrike verband tussen die Morele Herbewapening en die kerke, moet ons hierdie saak 'n bietjie nader bekyk.

Paulus word in hierdie werkie beskrywe asof hy 'n vooraanstaande lid is van die Morele Herbewapeningsbeweging. Sy eintlike stryd was teen die materialisme van sy eeu, waarvan sy optrede teen Demetrius, die silwersmid van Efese, 'n duidelike weergawe is $(23,24)$. Paulus was waarlik 'n rewolusionêre gees, 'n man met 'n geweldige opstandige gevoel in sy binneste. „He was an ecclesiastic who fought the ecclesiastics of his day for their narrow and self-righteous concept of churchmanship and for their level of personal, moral defeat"' $(80,81)$.

Van die woorde wedergeboorte en bekering hoor ons hier niks. Hier word slegs van Paulus se oortuiging wat geworteld was in 'n ervaring gespreek. Ons hoor slegs van getransformeerde lewens, maar nergens van wedergeborenes nie (pp. 43-47). Paulus se ervaring het hy opgedoen op die pad na Damaskus. Toe het God met hom gepraat. Die wonder van die hele gebeurtenis is nie dat God gepraat het nie, so word gesê, maar dat Paulus 
geluister het. Hier het hy opdrag gekry om 'n wêreldrewolusie teweeg te bring.

Ananias het Paulus besoek en van toe af was hy 'n getuie. Hy het nie gepreek nie, slegs sy ervaring aan ander meegedeel. Saam met hom was ook ander rewolusionêre geeste soos Barnabas, Markus en Timotheus. Paulus stig nie kerke nie, maar selle. Daar is 'n sel in Korinte, in Filippi, in Kolosse, in Thessalonika. Hierdie selle het weer die rewolusionêre gedagtes ingedra. En luister na hierdie stukkie universalisme: „He (Paulus) offers an experience that is valid and available for all men everywhere: white, black, yellow, East, West, worker, capitalist, Communist, non-communist, the faithless and the self-satisfied but ineffective christian....."

Werklik, kan 'n mens nog twyfel? Erger kan die onskriftuurlikheid nie aangedui word nie. Die Bybel is dig geslaan en net 'n paar gedagtetjies daaruit word gebruik om 'n andersins skoon-humanistiese gebou te versier. Sonder hierdie versiersels sou elke mens dit onderken het as 'n stukkie onskriftuurlike heidendom. Nou moet 'n mens slegs die stukkie vernis eers afkrap, maar dis tog maar deursigtelik.

Dink aan die verdraaiinge van die Bybel: Paulus beveg die kerk, Paulus rig selle op. Paulus as lid van die Morele Herbewapening is 'n gans ander Paulus as die een wat ons ken uit Gods Woord.

En so gaan Morele Herbewapening voort om die millioene te bereik. Hy maak gebruik van vooraanstaande en leiersfigure in elke land. In SuidAfrika word elke dorp en stad gefynkam om persone te verkry om 'n sel te vorm. 'n Paar uitgelesenes word gebruik om die uitnodigings uit te stuur. Eintlik word dit aan jou só voorgestel dat jy vereer word met hierdie uitnodiging, dat dit iets besonders is. Jy moet ' $n$ unieke toneelstuk bywoon wat in al die wêrelddele vol sale getrek het en wat geroem word as iets wat 'n groot verandering tussen werkers teweeggebring het. Eintlik is dit niks anders as 'n stukkie propaganda nie. Soms is dit advokate, prokureurs, regters en sodanige agbare persone-dan weer word professorekringe, industrialiste, direkteure van groot onderneminge, betrek. Ook die jeug, en veral die studente word nie vergeet nie. Studenteraadslede en veral die persone aan die spits van die georganiseerde studentegemeenskap is 'n uitverkore jagveld. Almal moet deelneem aan die groot rewolusie van Morele Herwapening. Dit is dan iets magtigs, iets groots, waarna die Pous luister en presidente van grootmoondhede. Alle volksprobleme vervaag soos mistigheid voor die son. 
En intussen, as 'n mens die saak reg ondersoek is dit niks meer as 'n storm in ' $n$ teekoppie nie, werklik 'n stigting van verwarring en wat die moeite van ondersoek nie ten volle loon nie.

\section{Slotopmerkings:}

'n Mens sou nog kon attendeer op verdere flaters in hul opvatting van die Skrif en 'n veelheid van foute aandui. Ons wil hier volstaan met 'n paar te noem.

(a) Openbaring: Ons tref hier tog 'n wonderlike opvatting oor openbaring aan. Deur die kerke word Gods Woord opgeneem as die enigste bron van Godskennis. By die sogenaamde, Guidance' word dit voorgestel asof God met jou praat, Hom aan jou openbaar. 'n Mens vra jou af of hier nie 'n subjektiewe en personalistiese openbaringsidee verkry word nie. Ons bedoel hiermee dat ons met ons verstandelike vermoëns moet uitmaak wat nou eintlik in die Bybel aan ons geopenbaar word. Ons bepaal nie alleen die openbaringsinhoud nie, maar gee ook die betekenis aan. Waar lees ons bv. van die vier standaarde of norme nl. van eerlikheid, reinheid, onselfsugtigheid en liefde as sodanig in Gods Woord? Sekerlik is hierdie deugde wat gevolg het op 'n verandering in die menslike natuur deur Gods Gees in die wedergeboorte. Maar-en hier vind u die personalistiese openbaringsbegrip-die Morele Herbewapening besluit met eie redegawes dat Gods Woord genoegsaam grond bied vir die stelling dat hierdie vier deugde uitgesonder kan word as die vier allerbelangrikste norme vir die mens se lewe. En as ons die vier hou, is ons goeie, deugdelike, ,God-controlled' wesens. Wat 'n klug! Dis soveel fariseisme. Ons besluit eers om vas te stel waarin 'n Christelike lewe bestaan en verklaar daarna onsself as ,God-controlled'.

Hierdie openbaringsbegrip bring natuurlik ook sy moeilikhede. Welke objektiewe getuienisse kan ons aanvoer dat God met ons gepraat het, ons gelei het? As twee persone nou duidelik verskillende leidinge ontvang het en hulle het al die toetse toegepas, hoe kan hulle mekaar oortuig? Hierdie sogenaamde toespraak van die Gees in ons binneste is niks anders as die gevaarlike leer van die innerlike lig wat elke mens in sy eie binneste het nie. Daaruit is al verskeie sektes gebore en dit kan alleen tot eiewilligheid en nooit tot gehoorsaamheid aan God bring nie. Eintlik het ons hier niks anders as iets wat opkom in jou eie gemoed en jyself is die eintlike bepaler van die inhoud van Gods openbaring aan jou, Laat ons ons ver daarvan hou.

(b) Beginselloos: Miskien wil die Beweging uit beginsel beginselloos wees. Hy wil nie oor beginsels disputeer nie, beskou beginsels as die oorsaak van soveei versplintering in die Christelike lewe. Sy doel is om alles 
en almal te verenig. Enige mens vra: hoe kan God en Mohammed, Rooms en Protestant, Christendom en heidendom verenig word? Die antwoord is dan eenvoudig: alleen deur 'n neutrale organisasie, wat nie Christelik en ook nie onchristelik is nie, in 'n Beweging wat nie koud of warm is nie, maar lou. So'n Beweging moet dus uit beginsel onsydig-Christelik wees.

(c) Sy praktyk: Ons wil veral oor die praktyk, juis omdat dit juis dan die kernpunt is van die Morele Herbewapening, 'n beskouing gee en kyk of hy iets besonders kan bied.

Ons het gesien dat sy praktyk veral rondom drie kernsake gegroepeer word: ,God-control, Guidance en change'.

Die leiers van die beweging sê daar is te min van God in ons lewens. Daar moet veel meer van God in ons lewens wees. God moet ons lewens vul sodat ons lewens God-controlled kan wees.

In ons antwoord op hierdie punt nl. meer van God, wil ons dit sê: in hierdie Beweging is daar glad te weinig van God. Ons het hierbo probeer aandui dat ' $n$ onsuiwere opvatting oor God daartoe meewerk. Ons gaan nie verder in op beginselbeoordeling nie, maar wil dit vanuit die praktyk beskou.

Om maar net elke more, in die stille vroeë oggend, te bid om Gods leiding en dan die dagtaak aan te voor-dit is inderdaad te min van God in elke dag. Dit is nie wat onder God-control verstaan kan word nie. Dit is in die praktyk ook die kernfout van hierdie Beweging. Hy stel hom met veel minder tevrede as wat die gewone gelowige as geestelike padkos verlang. Die beskuldiging is eintlik: Die geestelike lewe gaan bankrot, want God is daaruit. Nou word juis dieselfde beskuldiging 'n terugslaande boemerang: Onder Morele Herbewapening beleef ons die eintlike bankrotskap, want God is die hele dag uit jou lewe, behalwe so'n kwartiertjie in die oggend vroeg.

Hierteenoor staan die Skrifleer: Nie een enkele oomblik kan jy sonder God wees nie: of jy eet en of jy drink en of jy enigiets anders doen, doen dit alles ter ere Gods. Ja, selfs die sterwe is nie uitgesonderd nie, want in Rom. 14 sê Paulus: Of ek leef en of ek sterf, ek behoort aan die Here.

Hier het ons dan die kernfout: Godsdiens is diens van God. Hierdie diens van God omvat alles wat ons doen en dek die hele dag en nag van elke dag se bestaan. Die grootste fout van hierdie lewe was dat hy godsdiens gaan beperk het tot 'n besondere oomblik, tot 'n oomblik van gemeenskap: dan wanneer ek kerk toe gaan of huisgodsdiens hou; dan wanneer daar 'n verandering (change) in my plaasvind of wanneer ek in stille bepeinsing leiding (guidance) ontvang. 
Dit is juis presies wat godsdiens nie is nie. Godsdiens beteken dat ek 24 uit die 24 uur in diens van God staan. In my nederigste werk is ek besig om God te dien, in my sport, in my slaap, in my besigheid. Van godsdiens het ek geen oomblik vakansie nie. Dit is diens van God uit liefde met my hele hart, met my hele siel, met my hele verstand en met al my kragte. As daar één tydjie in my daaglikse lewe is waar ek God nie dien nie, dan is ek daar besig om ' $n$ afgod te dien. As daar één plekkie is waar ek dink dat dit nou nie eintlik godsdiens kan wees nie, dan is ek daar besig om 'n afgod te vereer.

Die Bybelse leer is dus: God is nie net elke oggend deel van my lewe en stuur en rig dan my dagorde nie. God is dwarsdeur die dag die getroue en allergenadigste Vader wat my geen enkele oomblik verlaat nie en ek mag God ook nie verlaat nie.

Laat die Morele Herbewapening nou iets beters aan ons mense gee as dit wat die kerke elke Sondag uit God Woord verkondig. Inteendeel: teenoor hierdie heerlike voortdurende gemeenskap met God, waarin die gelowige bely met ps. 73:23 „Nogtans is ek altyddeur by U; $U$ het my regterhand gevat"- -staan die Morele Herbewapening se bietjie "Guidance" flou afgeteken, bloedloos armoedig. Geen wonder dat die Oxfordgroep 'n vroeë dood gesterf het nie. Met Morele Herwbeapening sal dit net so gaan.

En as hierdie Beweging nog beskuldigend teen die kerke die vinger ophef met die bewering dat die kerke leeg loop, kan ons almal in aanbidding voor God staan en sê: maar die kerke het nog nooit doodgegaan nie. Die poorte van die doderyk sal dit nie oorweldig nie. Ons is egter getuies van meer as een dusdanige Beweging wat die weg van alle vlees gegaan het.

Aan lidmate van al ons kerke kom hierdie stuk met die beroep: ondersoek eers u eie erfgoed, u eie geloofsbelydenis met sy louter goud as dure skat. Ondersoek dan in die lig daarvan die aanbiedinge van elders. Telkens sal u bemerk dat dit wat mooi is in sulke semi-kerklike bewegings eintlik maar die minimum is wat $u$ eie kerk en belydenis aan $u$ gee.

Waarlik: dit wat Morele Herbewapening gee is so'n minimum dat 'n mens dit op 'n trippens kan skrywe.

Miskien moet ek ten slotte dan sê wat Morele Herbewapening si. Ek sien dit so: Die Bybel roep tot bekering, maar hierdie Beweging tot beskawing. Hier staan jy teenoor die mens: jy moet aan hom verskoning vra en 'n mooi ordentlike lewe voor die mens lei. 
Daarom is Morele Herbewapening vir my gepopulariseerde, verburgerlikte, vermenslikte, godsdiensagtige praktyk waarin die hoofsaak is die sedelike, die opregte, die voor die mens behaaglike lewe.

Daarom sal hy nooit by die gewone mens ingang vind nie, maar sal hy wees die godsdiens van die geleerde, die ryke, die man van aansien. Hierdie mense wil nie 'n godsdiens van gehoorsaamheid nie, maar 'n godsdiens waarin hulle self seggenskap het.

S. P. VAN DER WALT. 